\author{
DANIEL ROOD
}

\title{
HERMAN MERIVALE'S BLACK LEGEND: RETHINKING THE INTELLECTUAL HISTORY OF FREE TRADE IMPERIALISM
}

\section{INTRODUCTION}

In 1839, immediately following the formal end of "apprenticeship" in the British West Indies, and as debates over free trade continued to swirl in various circles of British and colonial society, the young economist and colonial bureaucrat Herman Merivale delivered a series of lectures at Oxford University. ${ }^{1}$ The auspiciousness of the moment did not escape him. As a cautiously optimistic supporter of emancipation and of free trade for the colonies, ${ }^{2}$ Merivale (1967:v) took the opportunity to celebrate the passing of the "old empire":

\begin{abstract}
During the continental war, and for many subsequent years, our colonial empire had been administered after no very regular pattern, but in accordance with certain received usages. While most of our colonies had free legislatures, their executive government was jealously retained within the control of the mother country. Their trade was fettered by the highly artificial restrictions of the so-called colonial system. Slavery, though assailed with great pertinacity, was maintained in a large proportion of them; together with the peculiar condition of political society which it engendered.
\end{abstract}

1. I would like to thank Bill Maurer for encouraging me to write this piece, and for steering me toward Merivale in the first place. The suggestions of NWIG's anonymous reviewers have helped me to clarify my arguments and put Merivale into context. I would also like to thank Laura Mitchell and Kate Nicholson for their careful readings and constructive criticisms of an earlier draft.

2. "Emancipation, taken at the worst, can only have brought this inevitable result [of West Indian ruin] a little nearer; taken at the best, it may have laid the foundation of a new and more solid edifice of colonial prosperity" (Merivale 1967:91).

New West Indian Guide / Nieuwe West-Indische Gids vol. 80 no. 3 \& 4 (2006):163-189 
Such shortcomings, however, he did not wish interpreted as reasons for ending the colonial project altogether. On the contrary, the recent attentions, critical and otherwise, lavished upon the British colonies had provided an opportunity for the fulfillment of the empire's universal promise, and the experimental nature of slave emancipation meant that the West Indian territories required British patronage more than ever. For, Merivale was not a believer in the categorical superiority of free labor. Nor did he believe that the unimpeded operations of the market would eventually lead to the extinction of the empire's "peculiar institution." Influenced by the population-driven arguments of Malthus and Edward Gibbon Wakefield, Merivale believed that the development of a slave economy had been a rational, capitalistic response to plentiful lands and scarce labor in the Americas, and that tropical plantation agriculture was most efficiently conducted on the basis of slave, not free labor. Thus the emancipation of half a million enslaved people represented a historically unprecedented act of economic self-abnegation and a "mighty experiment" in human affairs, to the great credit of the British people (Merivale 1967:91, 306-8; Goveia 1980:14043; Drescher 2002:59-161).

The transition from slave to free labor in the West Indies was therefore an event of world-historical import. Upon its success or failure hinged the future of millions of other bonded people, from the Niger Delta to Russia, and from the Ottoman domains to the sugar plantations of Bahia. Such was the urgent objective animating Merivale's lectures. The fact that there was no immediate economic motivation to spur the transition to a free labor economy in the West Indies, however, meant that metropolitan oversight was more pivotal than ever in the life of the colonies. He thus asks that his listeners contemplate "a reconstruction and great extension of the British dominion beyond the seas, on principles of internal self-government and commercial freedom" (Merivale 1967:vi). Wise and prudent political control from the metropole would prove indispensable to the founding of communities that might possess "the more valuable characteristics of advanced and well-regulated societies" (Merivale 1967:vii). These characteristics would include liberalized trade, free wage labor, agricultural exports, and the perpetuation of the plantation complex, all combined with increased political control for colonial elites. With these reforms, Merivale (1967:159) promised a glimmering future: "that empires as vast and wealthy still remain to be founded, and new branches of commerce as extensive and as prosperous to be created." The opening of a "vast confederacy" of trade would open new territory of employment for the capital and labor struggling in increasingly crowded conditions on the British Isles. In other words, it would be the expansion of colonial possessions that would safeguard the beneficial operations of the free market. In his desire to incorporate the axioms of classical political economy into the continued expansion of the British Empire, Merivale's writings express succinctly the ideology of free trade imperialism which would guide colonial policy after about 1840 
in Caribbean, African, and Asian colonies (Semmel 1970), ${ }^{3}$ and marked the "reformed" empire's departure from the second British Empire.

The second British Empire, argues C.A. Bayly, arose in the context of a "worldwide crisis" between 1780 and $1800 .{ }^{4}$ During this time of global upheaval, anticolonial nationalism in the Americas, South Asia, and the Near East, Jacobinism and peasant insurgency in Western Europe, and slave rebellion in the Caribbean merged into a single, overwhelming threat to elements of the British ruling class. In response, big landowners, financiers, Church, and Crown formed a profoundly reactionary alliance to salvage imperial glory. This reaction featured "proconsular despotisms," militant Anglicanism, and virulent new forms of racism to shore up elite rule throughout the imperial world. Furthermore, Bayly points out, the second British Empire, known for its worldwide hegemony and commercial dominance, was primarily motivated not by the desire to impose free trade conditions on an unwilling world, but by an ideology of agrarian improvement that valorized a stereotype of the feudal manor as the model, and the end, of financial striving (Cain \& Hopkins 1986:504-5; Bayly 1989:81). The re-creation of an idealized feudal past, ironically, would be considered a centerpiece of the same British Empire that was spearheading industrialization in the mid-nineteenth-century world. Big London financiers and industrialists who shared in this cultural mélange looked admiringly upon the West Indian slaveholders who most closely approximated the enviable combination of lordly status and bourgeois economic dynamism that elites of the second Empire hoped to obtain for themselves (Cain \& Hopkins 1986:505, 508). Bayly observes the "decline" of this imperial style after 1830, and its replacement by the abolitionist, paternalistic, free trade, and self-government ideals of the reformed "empire of free trade."

Merivale's lectures have been used as evidence of the break between these two sharply opposed discourses and practices of imperialism. In this piece, however, I argue that Merivale's immersion in, and use of Black Legend narrative forms positions him more ambiguously on the cusp of the "old" and

3. Semmel uses the term "free trade imperialism" to combat the idea, common in the historiography of the 1960s, that there had ever been a "mid-Victorian anti-imperialism" based on free trade ideology. Free trade ideology was, on the contrary, the means to maintaining England's status as the "Workshop of the World" with the peripheries of a formal and informal empire relegated to the production of raw materials for the benefit of England. I am less concerned with exposing the ulterior motives behind British free trade ideology, and more with understanding how theories of economic and political liberalism were articulated to colonial domination in the mid-nineteenth century, and the tensions that accompanied it. For a more recent elaboration of the relationship between liberal economics and Western hegemony, see Escobar 1995 and Davis 2001, but also Meek 1976. And for the links between liberal political theory and colonial rule, see Mehta 1999.

4. For other analyses of the second British Empire, which periodize and conceptualize it quite differently, see Halstead 1983 and Harlow 1952-1964. 
the "new" imperial ideology. Merivale depended on themes of Spanish cruelty, laziness, and incompetence for two intertwined and contradictory purposes. On the one hand, he mobilized a Black Legend "way of thinking"5 to sketch a caricature of the second British Empire, thereby justifying sweeping reforms of imperial policy. As an influential Oxford political economist, and later undersecretary for the colonies of the British Empire, Merivale's deployment of Black Legend themes was crucial to the successful propagation of the free trade imperialism of the reformed British Empire. On the other hand, his adoption of Black Legend discourse affiliated Merivale's proposed reforms closely with the most characteristic aspects of the second Empire. This affinity compromised the liberalism, reformism, and modernity to which Merivale staked a claim. We are thus confronted with the necessity of rethinking how Merivale has been located historically, and by extension, how we understand the constellation of ideas characterizing British imperial policy between approximately 1840 and 1900; the era of "free trade imperialism."

Significantly, the opening salvo of Merivale's famous series of lectures consists in a recounting of the history of Spanish colonial rule. He employed this history didactically, suggesting that it held important lessons for his contemporaries. Merivale's observations in these opening passages, and elsewhere throughout the Lectures, resonate with the critiques of Spanish colonialism known collectively as the Black Legend, inaugurated by Bartolomé de Las Casas's Short Account of the Destruction of the Indies. The curses of the old Spanish friar echo throughout Merivale's lectures on the history of Spanish colonialism, in which he condemns the "Other imperialism" for its laziness, its cruelty, and more than anything else, its strict mercantilist policies. ${ }^{6}$

The accounts Las Casas offered to the world were later utilized by Spain's English, French, and Dutch rivals to concoct the Black Legend. Spain's competitors used the Black Legend to describe the "other imperialism," which both shed a forgiving light on their own activities and justified belligerent conduct toward Spain's colonial possessions. Tales of Spanish brutality, corruption, imperiousness, laziness, decadence, and uncontrolled sexuality circulated among the Atlantic empires of the early modern and modern periods, giving credence and a humanitarian veneer to imperial projects according to the distance they could put between themselves and Spanishness. "Popish" or "Romish" conspiracy theory, and above all, racial theories associating

5. For an explanation of what is meant by thinking "in a certain kind of way," see Benitez-Rojo 1992:158.

6. For a comparison to the roles played by "Other empires" (aside from the Spanish) in the constitution of British imperial identity in the nineteenth century, see Turhan 2003 and Bayly 1989:51-62.

7. Keen 1969, Gibson 1971, Maltby 1971, Martínez 1991, García Cárcel 1992, DeGuzmán 2005. 
Spaniards with the "taint" of Arab, Jewish, African, and Indian blood "added color" to these stories. On the other hand, the Black Legend was used as anti-imperial morality play, and not only, as some scholars have suggested, as disingenuous ad hoc justification for encroachment on Spanish possessions. Whether used as the foil for imperialist or anti-imperialist arguments, the Black Legend has figured significantly in the formation of national and imperial variants of European identity, the British in particular. ${ }^{8}$

As an heir of the vibrant Black Legend strains of British imperial thought, Merivale can be thought of as a descendant of the tradition of Caribbean thought initiated by Las Casas. ${ }^{9}$ In this piece, I argue that the rhetorical power and the "common sense" of the doctrine of free trade imperialism relied upon a reinvigoration and reformulation of the Black Legend, a narrative that was built upon the ruins of Las Casas's utopian visions of an American New Jerusalem. I will argue that not only the introductory lecture, but Merivale's formulations of free trade imperialism as a whole were deeply indebted to the Black Legend tradition based upon the writings of Las Casas.

My paper will make a contribution to the genealogy of ideas which undergirded Britain's "liberal" empire of free trade after 1840. This reinterpretation intervenes in a number of important debates. First of all, it complicates the idea of a sharp break between the second and "liberal" British empires and instead suggests that the second Empire analyzed so well by C.A. Bayly continues in altered form, and gets articulated to industrial, not just gentlemanly or commercial capitalism. Second, scholarly engagement with the Black Legend has focused on Spain, often measuring the legend's degree of truth or untruth as a description of Spanish imperial policy, or its role in renaissance-era interimperial quarrels. ${ }^{10}$ This paper, however, deals with the role of the Black Legend in the ideological construction of the mid-nineteenth-century British Empire.

Furthermore, my essay highlights the interimperial character of intellectual exchanges that characterized the Atlantic World, challenging a number of recent works that seek to parse Atlantic history back into Dutch, British, Iberian, and Black Atlantic Worlds, to give but a few examples (Gilroy 1993,

8. DeGuzmán (2005) marshals an imaginative and rigorous analysis of nineteenth-century U.S. literature to uncover the prominent, but oft-forgotten role of the "off-white" Spaniard in the construction of Anglo-American imperial identity.

9. Thus it is a set of tropes which has been constantly reproduced, elaborated upon, and creatively re-written. Its very multiplicity suggests its continued efficacy as an imperial trope, but also makes the tracing of its genealogy difficult. See Maltby 1971 and Keen 1969 for some admirable efforts (DeGuzmán 2005:4-5, 27).

10. Keen 1969, Hanke 1971, Martínez 1991, García Cárcel 1992. Historians of Latin America remain on guard against the efforts of some scholars to "relight the once sputtering embers of the Black Legend" (Nesvig 2005:538). 
Canny 1999, Armitage \& Braddick 2002). ${ }^{11}$ As María DeGuzmán (2005:4-5, 27) perceptively observes, the Black Legend is a "fragmented ... story" that is "contagious and keeps migrating from country, to text, to author, to critic, and so on." The interimperial travels of the Black Legend, and its continuing transformation by way of these sojourns, argues against the re-parsing of Atlantic history back into separate imperial histories, which it threatens to do at present. This paper links the early Spanish conquest explicitly to nineteenth-century Anglo-colonial formations of modern knowledge/power. It is this cross-pollination and his comparison among empires that makes free trade imperialism thinkable for Merivale. In fact, he is unable to formulate his philosophy of colonialism without making recourse to other empires and their interactions with the British.

Why does the trope of the Black Legend could still make so much sense in the 1840s? The answer lies partly in the recent past of the second British Empire. Merivale was able to mobilize Black Legend discourse to mark out a break and justify the liberal, free trade empire because the second British Empire was so amenable to such analogy. The Black Legend retained its currency in the age of the twilight of the second Empire because it provided a still-effective tool for prying open a discursive space that helped the constellation of values known as free trade imperialism "make sense" in opposition to the "backwards" imperialism of the second British Empire. The latter was a strawman injected with life, it turns out, by the hated tyranny and laughable inefficiency of the Spanish Empire of Black Legend infamy. I thus go beyond arguments about the truth or falsehood of, or ulterior motives behind, the Black Legend propagated by English, French, and Dutch intellectuals throughout the early modern and modern Atlantic worlds. The Black Legend was more assiduously at work in the formulation of British imperial policy and identity than has previously been imagined.

At the same time, I explore the ways in which Merivale transformed what he inherited for different uses in a much different era. By importing Black Legend thinking into the logic of political economy, Merivale rewrote it as a story of inefficiency, mismanagement of workers/natives/slaves, the follies of monopoly, and other themes more germane to political economists and parliamentarians of the 1840s. It is no accident that Merivale felt the need to deal at length with the Spanish Empire. The Black Legend was an especially significant tool for Merivale during this period because he knew that the most direct challenge to the "mighty experiment" of slave emancipation

11. See also The Atlantic World: America and the Netherlands at http://international.loc. gov/intldl/awkbhtml/awkbhome.html and Rethinking the Iberian Atlantic at http://www. liv.ac.uk/iberianatlantic/; for a compelling exploration of the complexity and hybridity of Atlantic intellectual history, see Benitez-Rojo 1992:16-17 and Maurer 2002. 
came from the specter of flourishing Ibero-American slave economies: Cuba, Brazil, and Puerto Rico. The continued economic success of these Iberian colonies raised the hoary specter of fabulous wealth produced by liberalized trade that was uncoupled from human freedom. Thus the Black Legend during the era of emancipation takes on the guise, more than anything else, of Cuba, threatening to undo the entire Enlightenment project.

In Part One I will show the ways in which Merivale's history of the Spanish Empire was informed by Black Legend discourse. Part Two explores more deeply the colonial theories of Merivale, emphasizing the degree to which they were shot through with Black Legend themes. Part Two also offers an exploration of some overlooked aspects of the Lascasian Black Legend, and how it put its imprint on Merivale's propositions for colonial reform. In the conclusion I follow Merivale's updating of the Black Legend to his day. He ends with a discussion of Cuba, and this discussion highlights the paradoxical nature of Merivale's position. His handling of his day's Black Legend foreshadows the trajectory of the British Empire in the late Victorian era.

\section{PART ONE: HERMAN MERIVALE'S BLACK LEGEND}

Merivale's first lecture recounts in detail the history of Spanish colonialism in the Americas. He begins there because the Iberian colonial project was to provide the context in which his succeeding lectures, those laying out the relationships among colonial rule, free trade, profitability, and the civilization of primitive races, were to be understood. His understanding of the Spanish Empire and European colonialism in general was deeply informed by Black Legend thinking on the subject of the Spanish Empire in the New World.

It would be unfair, however, to accuse Merivale of parroting the worn stereotypes of oversexed and indolent Spanish conquistadors. In the body of the first lecture, he reviews the "peculiar virtues and vices" of the conquistadors, but warns that they have loomed larger in historical memory than their actual influence merits. Their adventures, while epic in proportion, were in fact short-lived, and did not overwhelmingly shape the subsequent course of Spanish colonialism: "After their era came that of the peaceful colonist," Merivale (1967:4) points out, "whose slow labours founded and consolidated the dominion" of the New World. He is also generous in his evaluation of the Spanish legal code, which provided for less barbaric treatment of slaves than in British domains, and is complimentary regarding the Spaniards' protection of Indian communities. On the other hand, he does run down the classic list of the Black Legend.

The distribution of political power was horribly unjust, with all authority concentrated in the hands of Spaniards, who themselves labored under a sys- 
tem of colonial government so labyrinthine that it proved "impossible to carry into effect any scheme for the amelioration of society" (Merivale 1967:11).

The most egregious of the institutional failures, though, was that of the Church. The clergy, left to their own devices in the "tropical" environment, were "notoriously lazy and corrupt" and "sunk in the utmost sloth and profligacy" (Merivale 1967:14). The torpid lexicon of the Black Legend fills Merivale's lecture on the history of the Spanish Empire, as can be seen in his damning depiction of the New World Church. Its decadent state was not reached merely though fault of the clergy, however. The "tropical" environment was a determining factor, and when combined with the oppressive and tyrannical institutions imported from the mother country, led to new lows. ${ }^{12}$ While Merivale concedes that the Inquisition was not as brutal or total as it was in Iberia, he proposes that this owed "to the general languor which pervaded all things in those regions of indolence" (Merivale 1967:14). Under these conditions, "the degeneracy of the Creole race ... was rapid." Instead of civilizing indigenous peoples, as colonial justification demanded, colonists were reduced almost to the level of the Indians themselves. "The courage of the Castilian" disappeared, he "forgot the use of arms," and when facing other European interlopers, he was "almost as powerless and terrified as the Indians themselves" (Merivale 1967:14). Cowardice in battle, here described, was another entry on the list of the classic Black Legend.

It is for the economic policies of the Spanish colonial system, however, that Merivale reserves his ire. "The commercial policy of the Spanish government towards its continental colonies," he declares, "exhibits as perfect a monument of systematic tyranny as any age has produced" (Merivale 1967:8). All imports and exports flowed through the single port of Seville, for the benefit of a small cadre of Crown-affiliated merchants, and as a result, the colonies were never adequately supplied with the goods or currency they required.

Because Merivale delivered his lectures in the midst of the emancipationist maelstrom of the late 1830s, his discussion of labor aspects of political economy is particularly freighted. Modes of recruiting and disciplining labor are of immense concern to Merivale, and his views are shaped by the Black Legend. The instatement of a system of rural free wage labor (ensured by coerced importation of non-White labor) forms the centerpiece of hopes for Merivale's liberal empire in the West Indies. Thus the peccadilloes of Spanish practices of enslavement, gleaned from the eyewitness accounts of Las Casas and others, play a major role in his first lecture. While coercion

12. This environmental understanding of racial characteristics was much more important than a gestating, but still less influential biological racism that would arise in the second half of the nineteenth century (Drescher 2002: 73-87, Graham 1990). For another analysis of environmental determinism of racial characteristics within the Spanish Empire, see Sarmiento 1960:1-23. 
is still very much a part of Merivale's colonial reform program, "slavery" itself is quarantined, understood as inefficient, de-civilizing, and illiberal, and attracting much blame for the other perceived failures of the Spanish (and "old" British) empires. Enslavement is both first cause and ugly consequence of imperial inadequacy. Native Americans

were driven in herds to the mines, forced to supply by their numbers the total want of skill and of capital under which their masters laboured, and their lives were wasted with the same reckless profusion with which the colonist of modern times wastes the powers which are placed at his disposal - the wild animals of the forest and the resources of a virgin soil. (Merivale 1967:5)

Merivale thus criticizes the practices of British colonial elites by way of analogy with the loathed Spanish. The regime of labor was also foundational in the construction of the Lascasian Black Legend. In fact, enslavement functions as an Ur-moment of the European conquest of the Americas in Las Casas's text. The first chapter of his account of the "destruction of the Indies" begins like this:

As we have said, the island of Hispaniola was the first to witness the arrival of Europeans and the first to suffer the wholesale slaughter of its people and the devastation and depopulation of the land. It all began with the Europeans taking native women and children ... as servants. (Las Casas 2004:14)

He insists that, of all the brutality, torture, and savagery introduced by the Spaniards into the province of Nicaragua, "the most insidious pestilence ... was the system whereby [officers] granted licenses to Spaniards to demand slaves from native caciques and nobles" (Las Casas:40). Both thinkers exhibit an ambivalent sense of the relationships between slavery and civilization: for Las Casas, abolition of Indian slavery paired with the importation of African slaves would help to save/create a Christian utopia. For Merivale, the abolition of outright slavery coupled with the forced importation of coolies and expropriation of arable lands from freed people could be used to salvage the Hobbesian, free-market society he sought to bring into being.

In Merivale's history, mines themselves were partly to blame for the troubled status of the Spanish colonial world. He points out that Indians were slightly better off in areas without silver and gold, although their treatment was no gentler (Merivale 1967:5). It is an integral aspect of the Black Legend that the plentiful precious metals controlled by the Spanish actually worked against them: with such easily gotten riches, there was little incentive to engage in "improvement." Instead of developing dynamic, wealth-producing societies, the Spanish were seduced by the booty capitalism of precious metal acquisition. With Indians forced down into the mines, digging up 
unheard-of riches in silver and gold, Spanish colonists had little to do except coerce native labor and expand their personal holdings. ${ }^{13}$

A curious addition that Merivale makes to his Black Legend of political economy is his attributing to the combination of abundant precious metals and despotic governmental regulation the unusual propensity of Spanish settlers to gather in towns and cities:

\begin{abstract}
The tendency was increased by the indolent habits of families, whose subsistence was amply provided for by the labour of others, and which had little temptation to accumulate wealth and embark in profitable undertakings, hemmed in and oppressed as they were by the jealous policy of their rulers. In this way the government may be said to have collected the people together artificially in towns. (Merivale 1967:8)
\end{abstract}

This kind of social engineering ("artificially"), and population resettlement is not to be commended, although other approaches to the state's wielding of bio-power (Foucault 1990:140-44) form the centerpiece of Merivale's hopes for postemancipation colonial societies. The interesting result of this artificial and indolent growth of cities is the development of a sprawling outlay of mutually isolated towns, each provided for by its respective countryside and having little intercourse with the outside world: "Thus each community dwelt apart, divided at once by natural and artificial barriers; and generation after generation remained as utterly ignorant and reckless of the fortunes of the neighbouring settlements, as of those of the most distant countries of Europe" (Merivale 1967:8). Merivale adds another element to his Black Legend of political economy. Classical political economy, which really developed as a set of prescriptions for national economies, emphasized the integration of national markets by the linking of country to city and city to city. Both linkages are necessary to create a market system with consistent prices, a flexible labor supply, and a supply and demand equilibrium. Thus the mutual isolation of cities, and the lack of communications between each Spanish American city and its hinterland, functions as negative example.

13. Once again Adam Smith is Merivale's source for the construction of his Black Legend of political economy. He cites Smith (for the third time in ten pages) as arguing that "Spain and Portugal were manufacturing countries before they had any considerable colonies. Since they had the richest and most fertile in the world, they have ceased to be so" (Smith 1863, Book 4, pp. 249-89, cited in Merivale 1967:9-10). Thus colonial windfalls deindustrialized Spain. This statement should not, however, be interpreted as representing Smith's vaunted anticolonial outlook. According to Semmel (1970), Smith was critical of mercantilism, not colonization per se, and cannot rightfully be deployed as a figurehead of the anticolonial disposition of free traders. 
This lamentable state of affairs shifted in the late eighteenth century. Not surprisingly, the reform of the Black Legend empire began with changes in political economy: "The lightening of commercial restrictions, as usual, preceded and introduced every other improvement" (Merivale 1967:15). To their credit, the "enlightened" Bourbon kings loosened the prohibitive trade regulations. But they were not to be the heroes of Merivale's free trade morality play, for "the measures they adopted were forced upon them by the progress of events." The epochal shift in Spanish commercial policy was the work not of enlightened monarchs, but of the British smuggler, whose contraband trade to the Spanish possessions drained untold riches from royal coffers, leaving the Crown with little alternative but to open trade, at least moderately. The British smuggler, then, instituted liberalization by the force of his own economic self-interest (an invisible hand operating on the margins of legality). "Simultaneously ... the industry and social condition of the colonies had made a sudden and almost unparalleled advance" (Merivale 1967:17).

Even with these wondrous revolutions in economic performance however, Merivale portrays a fabulously rich Mexican oligarchy that nevertheless produced no new wealth. Again the labels of the Black Legend are pasted upon Creoles who failed to produce dynamic economies both through their own weakness ("the spirit of speculation in mining ... made them the constant prey of needy adventurers") and through their cupidity ("the habit of extravagant and ill-regulated establishments ... [and] the prevalence of gambling"). But the final burden is always placed at the doorstep of the "wretched policy of government" which earned the wrath of colonial elites by closing in their faces the doors to political power, self-determination, and true wealth by depriving them of "education, employment [and] importance in their native country" (Merivale 1967:26). The violence with which peninsulares and Creoles went after each other in the years after 1810, then, comes as no surprise to Merivale. The Spanish have only themselves to blame for the loss of their colonies - had they been willing to share power, and "above all ... abolish the ancient system of [commercial] restriction ... Spain might have given another turn to the destinies of the new world, and laid the foundations of an order of things essentially different from any which has yet existed" (Merivale 1967:29).

This new chapter in the Black Legend of Spanish incompetence as a colonial power, composed by Merivale, reduces the drawn-out, complicated conflicts for the emancipation of Spanish America from a struggle for freedom to a struggle for free trade. For, Merivale (1967:32) concludes,

tyranny ... falls heavily only on the few, and is often endured for a long time through the acquiescence of the many. But the species of oppression which is produced by the spirit of monopoly, and affects the comforts and subsistence of the multitude, fosters that deep-seated discontent which needs but occasion and incitement to overthrow the strongest institution. 
Thus the Spanish Empire's worst offense was its failure to follow the precepts of liberal political economy.

The moral of the story from Merivale's perspective, is, I propose, twofold. First, he suggests that the opening of South America to British capital and industry is Spain's own fault. In this Merivale is merely bringing up to date the use of the Black Legend to justify English encroachment on formerly Spanish possessions. The other lesson - a much more significant one for our purposes - is that England needs to share political power with colonial subjects ... we could read this admonishment to the Spanish as being a program for the British: "by abolishing the ancient system of restriction, and adopting a comprehensive and liberal scheme of commercial government" we might be able to maintain our empire. Merivale has rewritten the Black Legend, transposing it to political economy to justify a shift to free trade imperialism and link the latter with free labor and continued colonial rule.

\section{PART TWO: UTOPIAS DEFERRED: SOCIAL ENGINEERING, SOCIAL ORDER, AND STATES OF NATURE}

In this section I will highlight some often overlooked aspects of the Lascasian Black Legend and show how its logic shaped Merivale's political economy. Utopian rhetorics tie them together. The historical evolution of Caribbean societies has long evoked for Caribbean thinkers the image of a utopia, or "no-place." 14 With the extirpation of indigenous populations, the Caribbean became an empty space/sign, a "virgin territory," a tabula rasa ripe for inscriptions of meaning, and amenable to ambitious, indeed unprecedented, projects of social engineering. Going further back in time, the European radi$\mathrm{cal} /$ socialist/utopian traditions of the sixteenth through eighteenth centuries owe much to the Caribbean, which often provided the setting used to personify utopia, and by extension to critique the absolutist, or catholic, or capitalist status quo in Europe. "In this way," Gordon Lewis believes, "the Antillean

14. Patterson 1969, Mintz 1971, Lewis 1983, Trouillot 1995. According to Trouillot, postrevolutionary St. Domingue was a "no-place" for the West. The West possessed no narrative tropes, no cognitive structures to absorb an event as radical and unexpected as the Haitian Revolution. Therefore the West was faced with a "failure of categories," and, barring the creation of new categories, had no language with which to speak the Revolution. The ontological crisis produced by the slaves' revolution was resolved, simply enough, by the "silencing [of] the [revolutionary] past." I am hesitant to accept Trouillot's declaration that Western thought simply refused entry to the troubling realities of the Haitian Revolution. I think that a more productive question would be to ask how the Western order of things was affected, uprooted, pushed, pulled, and contorted by the Haitian Revolution (Trouillot 1995:88, 106). 
reality became the raw material for the construction of the European radical dream" (Lewis 1983:86).

At the same time, Caribbean and mainland American colonies facilitated the growth of utopian visions advocating capitalism and the modern state. The utopianism of classical political economy and political theory was inspired by the possibilities of state power having complete sway in colonies..$^{15} \mathrm{In}$ fact, some scholars have argued that the institutional and ideological apparatuses characteristic of the European nation-state originated as a set of instruments for imperial administration. These scholars propose that the colony be understood as a specie of political space where more intrusive forms of government action have been possible, as a "laboratory" enabling ambitious experimentation in new technologies of governance (Bayly 1989:123-24). ${ }^{16}$

Such fantasies of colonial possibility have Iberian roots (Silverblatt 2004). Before the colonial projects of the other European powers, the Inquisition in the Americas taught the Spanish Crown that it could "consolidate colonial state power in ways that would have been unthinkable in Europe" (Silverblatt 2004:4). In particular, inquisitors hoped to strip away all "illusory" social bonds to reach the essential truth of race and descent, thus "embroidering race thinking into the fabric" of state power at the outset. European state-making can be tracked ultimately to sixteenth-century Iberian colonies in the Americas. It was here that the "dance of bureaucracy and race" characterizing operations of modern state power was first traced out (Silverblatt 2004:4, 23).

It was not merely the Inquisition that helped give rise to modern state power, however. I would like to suggest that it was also the critique of the Inquisition and the other characteristics of Iberian colonial rule that were linked to it by way of the Black Legend that gave meaning to the imperial and state-building projects of the other European powers. The Iberian colonial project should be seen as an enabling condition in the rise of a Europeancentered era of modernity defined by the intersection of various "reasons of state": bureaucratic rationality, race thinking, and capital accumulation. The utopian thrust of modern state projects (the fateful intersection of liberal

15. Karl Polanyi has observed the strong utopian elements in classical political economy. As a perfect, self-regulating system of markets, governed only by its immanent rationality and the human "nature" of utility-maximizing individuals, the world envisioned by such thinkers as Mandeville, Mill, Malthus, and Smith resembles what Polanyi aptly described as a "stark utopia": a world where the exigencies of hunger and cold would make redundant the political and social lives of real people. He also points out that, historically, it has "required statecraft and repression to impose the logic of the market and its attendant risks on ordinary people, who have ... acted to protect themselves from the vagaries of the market." Thus "laissez-faire was planned; planning was not" (Polanyi 2001:135).

16. As William Beinart (1989:144) notes, "in the authoritarian environment of the colonial world, officials could have more influence than in Britain where private landowners were more powerful in relation to the state." 
political economy and imperial glory) must also trace its genealogy ultimately to the Iberian conquests (and commentary about them) in the Caribbean and the rest of the New World (Mignolo 2000:50; Silverblatt 2004:4, 23).

Indeed, the utopian projects associated with the Caribbean began with Las Casas on Hispaniola. Convinced that he was in the presence of a prelapsarian people, Las Casas undertook the conversion of the Indians with the weight of Biblical prophecy on his shoulders. His concern for the Indians' well-being and Christianization was not rooted only in what scholars have identified as his "medieval humanism," although his outrage was certainly inflamed by the tremendous suffering and cruelty he witnessed. He was motivated by the possibility that a new Christian civilization could be cultivated among the innocent people of a "new world" - the kind of world no longer possible in Europe. Las Casas's self-fashioning as a trustee for Indian peoples, and his complaints about the excesses of the conquistador and the encomendero, were rooted in his utopian vision for the New World, as was his early support for the African slave trade. His initial recommendation to import African slaves as substitutes for Indian ones is indeed hypocrisy, but it is also much more.

Las Casas's advocacy of the slave trade was grounded in his utopian dreams for the New World. Because Africans were considered by Spanish thinkers of the time to be implicated in the violent late-medieval and early modern worlds of Muslim conquest, the Crusades, and the Reconquista, they could not be categorized as "innocents" - people who had not heard the Christian Word. On the contrary, in the minds of Reconquista intellectuals, Africans had been offered salvation, and flatly refused it (Hiskett 1984:202-6; Robinson 2000:88-89). Thus Africans, unlike Indians, could be "justly" enslaved, and for Las Casas did not require the same care because they did not hold the same promise as obedient, faithful, and unsullied proto-Christians. Through the importation of Africans, who were more polluted by sin than European Christians, he could appease the conquistadors clamoring for laborers and save the Indians from destruction, thus shepherding his flock to safe pastures.

Indians, in stark opposition to fallen Africans, made Las Casas positively rapturous. The austere simplicity of their lives evoked comparisons to the "Desert Fathers" of the Old Testament (Las Casas 2004:10). Las Casas repeatedly refers to them as "gentle lambs" or like "sheep ... waiting patiently" to be slaughtered. Hoping to convince the King to intervene on behalf of native Americans, Las Casas $(2004: 11,46)$ adopted language that the New Testament uses to describe Jesus Christ. Their innocent and pure natures made them the ideal object of proselytizing efforts, for they were "open ... as can be imagined," "unassuming, long-suffering, unassertive and submissive" (Las Casas 2004:9-10). In Las Casas' gruesome narrative, his crushed utopian hopes for a New Jerusalem were shockingly embodied in the battered, burned, diseased, and crucified figure of the noble savage of America. 
Interestingly, the well-organized social order that existed among Caribbean Indians was as enticing and promising to Las Casas as the primitive Christianity he discovered among these Americans. Las Casas looked at the New World and saw large towns, dense populations, and fecund nature. Unlike other early observers (Columbus, Cortés, and others), however, who focused on the plentiful gold and silver circulating among different Indian groups, it was the hierarchical order of Caribbean (and later, mainland American) societies which really made the Spanish friar blush with pleasure. He missed no opportunities to emphasize the finely articulated and robust status hierarchies into which American "kingdoms were organized." Las Casas wrote effusively of the kingdom of "Xaraguá," which the conquistadors encountered on Hispaniola. While the common folk of the kingdom were "utterly faithful and obedient to their own native lords," the nobles of the kingdom displayed "refined language" and "cultivated court discourse." Indeed, "nowhere else were the people of such quality and breeding, the leading families as numerous and as liberal ... nor the inhabitants as handsome" (Las Casas 2004:21).

In the Aztec empire, Las Casas and his companions encountered yet greater nobility. He writes that "local citizens" entertained their imprisoned lord by dancing for him. What Las Casas chose to report of this impressive areito is significant:

\footnotetext{
The entertainments were organized with close attention to rank and station, the noblest of the citizens dancing nearest the building where their lord was being held. Close by this building, then, danced over two thousand youths of quality, the flower of the nobility of Montezuma's whole empire. (Las Casas 2004:50)
}

Explicit concern for the destruction of nobility, and the social hierarchy as a whole, is repeated throughout Las Casas's narrative. Witnessing the enslavement of Indians in Guatemala, his indignation is most aroused by the thoughtless humbling of nobility: "I myself saw the son of one of the leading citizens of the city branded with His Majesty's mark as a common slave" (Las Casas 2004:61).

Conquistadors" upsetting of "natural" social hierarchy was not limited to indigenous social classes. Las Casas evinces well-known concern for the terrible conditions under which Indians were forced to work in mines, but the gendered aspect of his accounts are important. He reports a situation in which gold-hungry Spaniards put "the women to labour in the fields ... properly a task only for the toughest and strongest of men." He reacts with indignation to the treatment of women and men as equals: "the men died down the mines from overwork and starvation, and the same was true of the women who perished out on the estates" (Las Casas 2004:24). 
Finally, his concern for social order colors his judgments of his own countrymen. In fact, the raison d'être of Las Casas's famous book - the mistreatment and murder of native Americans - is refracted through the prism of social status-as-divine order. "The reason the Christians have murdered on such a vast scale," he reports, "is purely and simply greed. They have set out to line their pockets with gold and to amass private fortunes ... so that they can then assume a status quite at odds with that into which they were born" (Las Casas 2004:13).

The repetition of these themes in the Brief Account could be interpreted as a stratagem to convince the Crown that Indian societies would make great contributions to the Crown as they were, and that the conquistadors should be stripped of their power and removed at once, for they were only destroying an already glorious, wealthy, and pious addition to the expanding empire. Others have argued that Las Casas was simply "a man of his time." Anthony Pagden tags Las Casas as a "social conservative" committed to ideals of divinely ordained kingship, and orderly, hierarchical structures with nobility and clergy in leadership roles (Pagden 2004:xiv). But it seems apparent that the upsetting of social order, the reduction of "leading citizens" to slaves attracts comment more than the infinite number of atrocities Las Casas claims not to have had the time to include in his account. The question remains: why do these episodes in particular wield instructive power in his mind?

Las Casas, unlike other "social engineers" who followed, did not desire to create a "virgin territory" upon the bones of indigenous people. To the contrary, Las Casas argued that a "just government must accommodate itself to the peculiar conditions and the disposition of the governed; the new possessions are not a tabula rasa upon which Spain may imprint its own religious and cultural character" (Lewis 1983:53). The New Jerusalem Las Casas hoped to culture in the New World would be built upon the political and social foundations of the indigenous people. At the same time, the ambitious social engineering project of Las Casas (2004:87) called for "social planning ... town planning, community organization of work, eugenics, state-sponsored arts and education." Thus Indian society, as a state of nature, was innocent, clean of sin, and ideal, but also required serious intervention to bring on the New Jerusalem, starting with mass religious indoctrination and conversion.

Las Casas pairs his contentions about the Indians' naturalness and innocence with descriptions of their highly articulated class structure. The latter is precisely the characteristic upon which he focuses his utopian hopes. More important than the innocence, purity, or submissiveness of the Indians, was the existence of what later Caribbean thinkers would call a "natural leadership" (e.g. Patterson 1969). The "native elites" upon whom the Crown and the Church could depend as indispensable mediators and forces of order in the Hispanicizing and Christianizing process would eventually fulfill the promise of a true community of believers on par with the "Desert Fathers" of 
the Old Testament, or the sheep-like apostles of Christ in the New. That the Spaniards' colonization policy has been above all committed to "suppressing the native leaders" (Las Casas 2004:13), only proves the necessity of ending the rule of the conquistadors. Their greed and ambition pollute the eschatological air of the "new world."

The dialectic between seeing utopia as natural and as the outcome of social planning suffuses the utopian tradition. ${ }^{17}$ The particularly colonial aspect, I propose, lies in the concern with cultivating a "natural leadership" or "native elite." The projects of Las Casas stand as an early example and are taken up by Merivale. The trope of a "utopia deferred" (by the destruction of the "native elite") formed one of the sturdier pillars in Las Casas's anti-conquistador edifice, constituting a particularly cogent argument. As such, the tragic trope of the destruction of a racialized "natural leadership" became an important part of the Black Legend narrative and was available to Merivale, who used it to great effect. ${ }^{18}$

I do not propose that Merivale was directly in thrall of Lascasian embellishment - such an unmediated relationship to Las Casas was neither necessary nor possible in nineteenth-century England. The legend had by then seeped into English thinking and become endemic to national culture in a variety of ways (Maltby 1971). In fact, Merivale depends entirely on "modern" historical sources to build his account of the Spanish Empire, especially German historians like Alexander von Humboldt and Leopold von Ranke. ${ }^{19}$ Rather, this particular element of Black Legend discourse, because of the utopian projects of Las Casas, and two centuries of intellectual work that kept these ideals alive, was not only available, it confronted any kind of historical thinking on the Atlantic world, thus profoundly informing Merivale's transposition of Black Legend

17. Neil Smith (1990) points out that the ideological naturalization of various socially constructed realms of human experience, "Nature" in particular, is a characteristic aspect of western colonizing logic.

18. David Scott (2004:168) suggests that the tragic mode of emplotment comports best with an era "of postcolonial crisis in which old horizons have collapsed or evaporated and new ones have not yet taken shape ... [the tragedians, for C.L.R. James] wrote in ambiguous moments of historical crisis and transformation, when old certainties were coming apart, when old securities were disappearing, and their tragedies capture the paradox of conflicts that offer no guaranteed resolution." The appearance of tragic elements in Merivale's story, seen from this perspective, certainly makes sense, considering the paradoxial nature of his attempts to write the transition from slavery to freedom within the conceptual confines of continued capital accumulation.

19. This direct dependence on German historians highlights the need to think across empires, nations, and "national cultures" that I have tried to emphasize here. The connections between the genesis of the modern discipline of history, formulated by such scholars as Ranke and Humboldt, and the Black Legend of Spanish colonialism which these historians in one way or another bequeathed to Merivale, would be an interesting project to pursue. 
thinking to the realm of political economy (in its colonial guise). In fact, the rationality of the Black Legend is tacit, enabling him to assume knowledge of its fine points by the reader. When beginning his historical account of Spanish colonization, he explains that "the miseries which that discovery entailed upon the defenceless inhabitants of America have been too often and too vividly described to need any recapitulation" (Merivale 1967:5). ${ }^{20}$ This availability facilitated his criticism of the second Empire, and his signal elaboration of free trade imperialism. Nevertheless, Merivale's evaluations of the Spanish Empire are built upon Lascasian themes with remarkable exactness.

The political administration of the Spaniards, in Merivale's mind, had been an unmitigated disaster, with "power ... exclusively in the hands of Spaniards." He proceeds to make the interesting point that while the same has been true in British colonies, these have a good reason for excluding colonials from the halls of power: within each colony reigned a democratic social structure which would be ruined by elevating certain members of that society to high official ranks, "artificially" creating an undemocratic elite by bestowing self-government upon West Indian Whites. In the Spanish colonies, on the other hand, there had been a landowning aristocracy and an otherwise ranked society that could easily have accommodated home rule adjustments while maintaining order. Alas, the chance was squandered, for efforts to improve Spanish colonial society were frustrated at every turn by overregulation (Merivale 1967:12). "It is one of the worst features of the policy of Spain," he concludes, "that having under its hand these elements of orderly and rational institutions, it systematically refused to employ them, and degraded and irritated the possessors of rank and wealth by excluding them from every public trust." Castigating the Spanish Crown for its neglect and eventual alienation of its colonial "Creole" elite, Merivale echoes Las Casas's desire to cultivate a "natural leadership" - the instrument through which colonial utopias could be constructed.

Merivale's state/utopian fantasies are fueled by the promise of unhindered power in the colonial world. Merivale's defense of continued colonial rule is based upon a Malthusian image of England as a container overflowing with capital and with people. What is more natural, he asked, than for those materials to flow into areas of less density? Merivale quotes Edmund Burke approvingly: "It is as natural ... for people to flock into a busy and wealthy country, that by any accident may be thin of people, as it is for the dense air to rush into those parts which are rarified" (Merivale 1967:138). Moreover,

20. Referring to an English book of 1660, Maltby (1971:132) points out that the Black Legend was by then so widely accepted that citation of authorities had become unnecessary, for "the author was telling his readers what they already knew, and the millions of dead Indians required no more documentation than did the tyrannies of Alba or the instruments of torture in the ships of the Armada." 
colonial settlement is central to English identity, an "instinct" that inheres in "almost all classes of society." Colonialism, then, is "natural" in two ways: as an instinct of the Anglo-Saxon, and as a survival mechanism triggered by overpopulation (Merivale 1967:138).

While portraying colonialism as the "natural" movement of Englishmen seeking land, labor, and employment for their capital, Merivale concedes that leaving "nature" to its own devices is not sufficient in the current, West Indian case. There is much more involved in the English colonial project than the self-regulating mechanisms determining the behavior of molecules under laboratory stimuli. ${ }^{21}$ Civilization itself is at stake:

It is by the migration of barbarous tribes that the whole earth has been peopled; by the colonizing genius of some more refined nations, that its civilisation, as far as that has hitherto proceeded, has been effected. Every recorded fact in the history of man seems to indicate these as the appointed means through which his social development takes place. (Merivale:138-39)

Merivale presents a sweeping reading of world history that, by conflating crosscultural interaction with colonial rule, and positing colonization as the motor force of history, suggests that civilization itself depends upon the judicious use of colonial-style population control that will be employed to produce a natural society. Although one must concede that the utopia imagined by each of these two thinkers is distinct from the other (Las Casas's Christian utopia opposes Merivale's stark utopia of a marketized ruthless nature) the characteristic dialectic of colonial utopia, initiated by Las Casas, reappears in Merivale.

Let us take a look at how this sweeping view of history will be applied to postemancipation policy in the Caribbean. Merivale assumes that nonEuropean people's only hope to stem their own decline and eventual extinction is through submission to the tutelage and the biogenetic intervention of Europeans. Merivale (1967:320) thus takes to task idealistic abolitionists who say, "let the plantations rot!" He warns them that a population of independent "Negro" yeomen who lack the guiding hand and everyday influence of Europeans will slip inexorably back into the savage state of "indolence and apathy so natural to their climate and condition" (Merivale 1967:320).22

21. Drescher (2002:88-89) points out the important role that experimental rhetoric played in the postemancipation debates. Figures all along the political spectrum mobilized this rhetoric, and its accompanying fetishization of statistics and empirical evidence, to forward their arguments. However, see Poovey 1993, which traces the suspect status of the "science" of statistics in the 1830s.

22. In voicing these concerns, Merivale prefigures the Negrophobic authoritarianism of later writers such as Carlyle, Trollope (1859), and Froude (1888). The differences between Merivale and these three slightly outweigh the similarities. These three are nostalgic both for the era of slavery and for strong rule by the Home Government, while Merivale sees both as evils to be eradicated, although, as I have suggested, problematically so. See Holt 
As of 1841, "civilization" in Jamaica was holding up despite the smallholder phenomenon, mostly because of the high wages produced by price regulation on sugar. As a result, the "negroes" were spending lots of money on "their love of luxury and display." The inflated wages associated with price supports on sugar helped maintain the bustle of commerce because the "particular wants" of "the negro" had been stimulated by the availability of commodities and his possession of cash. ${ }^{23}$

These artificially high wages eventually had to decrease, however, because they were "unnatural." According to Merivale, the survival of economies and societies in the long run depends upon their adherence to the "natural" laws of the market. Although Merivale considered price and wage supports inadvisable in the long term, the situation they had engendered among ex-slaves nevertheless illustrates the role that colonial policy would have to play in the construction of a free market utopia in the colonial world - necessary, because, in Merivale's (1967:276) mind "the inclination of men for the ease and independence of pastoral, semi-savage life, a propensity which seems to overcome that of self-interest, even in the most enterprising and industrious races, undoubtedly places great obstacles in the way of civilization." 24 So the cultivation of needs, and the accompanying willingness to labor for wages that leads to the accumulation of capital and the development of civilization as a whole must be enforced by concerted state action where land is plentiful. Once wages take their inevitable dive with the removal of "artificial" regulations,

these acquired tastes [of freedpeople for consumer goods] will die away, from the utter impossibility of gratifying them. Each negro will be able to support himself in tolerable comfort; but, without the aid of capital, he cannot produce surplus wealth; without it, therefore, he must remain a stranger to both the wants and the refinements of civilization. The example of Hayti is before our eyes. (Merivale 1967:320)

1992 on the transition to biological racism made necessary by the perceived failures of emancipation, and as a new way (in the absence of the de-civilizing effects of slavery) to explain continued backwardness in the West Indies. This explanation, tied not only to the conundra raised by the "problem of freedom," but to the rise of social Darwinism and scientific racism, however, would not become a significant feature of the British intellectual scene until after the 1840s. The Jamaican planter Bryan Edwards, Cuba's Arango y Parreño, Argentina's Sarmiento, and the English economist Edward Gibbon Wakefield offer more compelling comparisons to Merivale. The first group is also to be distinguished from the second in that the second tried to integrate Lockean political liberalism with the institution of slavery, while Carlyle and his epigones had no affection for democratic notions (Sarmiento 1960; Benn 2004:19; Gomariz 2004).

23. For a compelling take on the cultivation and refinement of desire as an index of civilization among political economists, see Moloney 2005:237-38.

24 . With the benefit of hindsight, Merivale would realize the contradictory nature of this position. The contradiction between political liberalism and systematic colonization is discussed in his retrospective 1861 preface, p. vii. 
Haiti, the Black republic, the very negation of modern civilization (Trouillot 1995) in Merivale's mind awaits - unless a way is found to return the proportion of capital, land, and labor to its "proper state." For followers of Smith and Malthus such as Merivale, the "proper state" was meant to suggest a situation in which the poor are competing over jobs because there is not enough land for them to support themselves on and too many laborers for them to demand "unnaturally high wages."

So how does Merivale plan to reinstate a "natural" equilibrium of land, labor, and capital in West Indian islands such as Jamaica and Trinidad? He advocates a kind of free trade authoritarianism in which laborers would be systematically imported, for their own good: we must not leave emigration "to be wholly settled by the voluntary proceedings of individuals. Emigrants of the lower orders are among those classes of subjects to whom all governments owe the exercise of a sort of protective authority" (Merivale 1967:321). Not only will the emigrants, subjected to forced removal from their homes in the East Indies, "Ceylon," "Hindostan," and the southern United States somehow be objects of philanthropic uplift. Intelligent colonial policy will also save Afro-Jamaicans from the looming threat of atavism which drools eagerly over their peasant freeholds.

It may go without saying that Merivale is not merely engaging in disinterested humanitarian speculation here. His program is of universal importance. As a disciple of Malthus, Merivale realizes that continued economic development and capital accumulation would become more and more difficult in an England crowded with capital. Continued accumulation required the continual opening of new, fertile lands for the employment of such capital. Otherwise, diminishing returns on investment would soon bring the capitalist system as a whole to a standstill. ${ }^{25}$ Thus, continual colonization and settlement is necessary to the climb of European civilization. But on each new frontier, the same problems will arise: a plethora of arable land will draw off any labor force, leaving "enterprising men" with no workers through which to produce surplus wealth. A dispersed colony of settlement, in the colonies with large exslave populations anyway, confronts us once again with the specter of "Hayti." Without some mediating mechanism, capitalists would have to pay prohibitively high wages to employ workers. The plantation peripheries, supposedly well stocked with laborers furnishing tropical goods to British industry and consuming goods produced by those industries, will never develop into promising fields of employment for metropolitan capital unless something is done. Merivale resolves this conundrum, his version of the fundamental contradiction of modern capitalism, by advocating systematic, state-sponsored immi-

25. Merivale (1967:97, 255, 271-72), as a follower of Malthus and the physiocrats, had great faith in the productive powers of good soil, prioritizing it over labor and capital, the other of the classic "factors of production." 
gration and a global indentured labor trade. In the colonial world, the stark utopianism of the dismal science is at full extension.

Malthus considered the difference between rates of population growth and rates of agricultural production to be an inescapable limit, acting as a check on economic development, population growth, and industrialization. While Malthus concluded this to be an ineluctable reality of the human condition, Merivale, following Wakefield, saw systematic colonization as a solution: through the simple exportation of the Malthusian cycle to the colonial world, the metropole could finally transcend it. The stark utopia of classical political economy can be realized in the colonial world, thus allowing England to transcend the Malthusian limits that had ruled with an iron hand across the history of human civilizations. ${ }^{26}$

This set of policy proposals complicates Merivale's condemnation of the slave trade and slavery. On the surface he seems untroubled by the resemblance between the slave trade and the coerced migration of thousands upon thousands of non-White laborers from other realms of the empire (Look Lai 1993, Northrup 1995). ${ }^{27}$ Yet, from his realization of the "necessity" of systematic indenture arose Merivale's anxiety regarding the potential of free labor in colonization. For if colonial expansion is a necessary fix for the continued accumulation of capital by England, and historically colonies have depended on slave labor because of the lack of a reserve labor pool in those locations, then labor must be coerced until there is a large enough population to compel people to labor by necessity. So, if the future of civilization (and its past, as we have seen) depends on colonial expansion, the whole Enlightenment project of linking freedom and free markets to the production of wealth, particularly significant in the age of slave emancipation, is thrown into doubt. Since the colonies will not populate themselves and will not play their necessary role vis à vis the metropole unless they are fully colonized, (possessing the "proper" ratio of land and labor), coercion is indispensable to capital accumulation.

\section{CONCLUSION: SPECTERS OF CUBA}

Merivale's Black Legend was not limited to casting aspersions on the distant past of the now decrepit Spanish Empire. Highlighting this decrepitude was

26. The fact that population increases at a much higher rate than agricultural productivity "implies a strong and constantly operating check on population from the difficulty of subsistence. This difficulty must fall somewhere, and must necessarily be severely felt by a large proportion of mankind" (Malthus 1999:13).

27. Merivale's prescriptions ended up being very influential in West Indian policy. Dennis Benn (2004:37) argues that Lord Grey instituted a "Merivalean policy" when he used increased land prices, a head tax, the criminalization of squatting, and the cultivation of European consumption habits to force freed people to return to the plantations in Trinidad. 
comforting to Merivale, but it remained the Spanish Empire which hovered most threateningly in the face of liberal empire. In mid-nineteenth-century Cuba, a barbaric and cruel slave system had replaced the older, benign slave system, because of Cuba's rise as the epicenter of global sugar production. Merivale attributed the "transformation in slavery" that had occurred in Cuba to the coupling of slavery with high-powered capital accumulation. ${ }^{28}$ This leads to excessively brutal exploitation. "The vices engendered by the increase of slave cultivation," Merivale (1967:40) laments, "extend ... through all classes of society. Wealth is now as exclusively and sordidly pursued by the Spanish planter as it ever was by the Dutchman or Englishman." The economic self-interest of Spaniards, long disparaged as being lacking, or at least fatally compromised by langor and incompetence, has now surpassed the Protestant ethic of the Dutch and the English. It is the intensification and expansion of chattel slavery that has made this shift possible. Although he attempts to spin this fundamental transformation in the "Castilian character" in a negative direction, there is a deep ambivalence that disturbs his admonishments of the Cuban elite. They are spurned yet grudgingly admired. He cannot help but compare Cuba favorably to the British West Indies, which are decadent and poor, even before emancipation, but especially after. He seems taken aback and troubled by the wealth produced by the slave economy. With untouched soil at their disposal, these colonial elites of the Spanish Empire have combined novel industrial technologies, the benefits of liberalized trade, and the labor of almost half a million slaves. ${ }^{29}$ This is why the Cuban phenomenon is so profoundly disturbing: The flourishing slave society of Cuba stands as a living challenge to the linkage between free labor, free markets, and the production of wealth in an empire, and threatens to blur the line between slavery and freedom, which Merivale is trying so desperately to draw, within the colonial logic of capital accumulation. Thus the Black Legend of Spanish colonialism continues to haunt not only Merivale's text, but the larger text of nineteenth-century political economy, social science, and philosophy.

In a small way, Merivale came to realize the paradoxical nature of his position in later years. In 1861, Merivale added a preface to the re-publication of his Lectures, contextualizing them in the heated debates over emancipation and self-government for the West Indies that had defined the late 1830s. He

28. Paul Lovejoy (1983) coined the apt phrase to describe a similar series of changes happening over a much longer period in various African societies.

29. Arango y Parreño, one of the most important intellectuals of the Cuban slaveocracy, was instrumental in theorizing the modernization and industrialization of slavery. He made sustained attempts at harnessing the principles of political economy and political liberalism to a slave society. For that reason, he makes for very interesting cross-imperial comparison with Merivale (Tomich 2003, Gomariz 2004). 
admits, in retrospect, that the tide of history has receded from the shores of the Caribbean, and most of the contributors to that debate, the "sect" of free trade imperialists like Wakefield, are "already almost forgotten" (Merivale 1967:vii). He does insist that the "closet speculations" of this "sect" have had immense effect on colonial policy in the 1840s and 50s, but with the benefit of hindsight sees the essential paradox of his school of colonial reformers:

They wished at once to give full municipal freedom to colonists, and to tie down the land system of colonies by strict regulation. The latter end of their commonwealth forgot their beginning. They did not apparently anticipate that, when they had prevailed on the home government to make their experiment, the first demand of each emancipated community would be to get rid of their favourite land system, and adopt methods of its own; or that the very fulness of that self-government, of which themselves had advocated the concession, would render it impossible for the mother country to resist this demand. (Merivale 1967:vii)

Writing on the eve of the imposition of Crown Colony government, it seems that the resolution of the paradox offered by the attempt to incorporate political with economic liberalism has been realized: it is political freedom for the colonies that must be dispensed with, sacrificed to the interest of systematic colonization. Thus the dream, the "mighty experiment" of marrying political and economic liberalism to colonial rule proved unrealizable. The utopia was deferred as political liberalism was sacrificed to economic liberalism.

But even during the first flush of full emancipation and imperial reform, Merivale could not completely deny this reality. From the start, as I have been arguing, he had one foot in the nostalgic, patriarchal, belligerent disposition which characterized the second Empire (ca. 1790-1830). It was thus from the outset embroidered deeply into the theory of free trade imperialism that would define the British Empire between 1840 and 1900. Longing for the social hierarchy and political control of a free market utopia characterizes Merivale's Lectures, complicating oppositions between the pre- and postabolition British Empires, as well as between the "free trade empire" and the Cuban, Brazilian, and southern United States slave societies of the period.

\section{REFERENCES}

ARMitAge, DAVID \& Michael J. BRADDICK (eds.), 2002. The British Atlantic World, 1500-1800. New York: Palgrave MacMillan.

BAYLY, C.A., 1989. Imperial Meridian: The British Empire and the World, 1780-1830. London: Longman. 
BEINART, WiLliam, 1989. Introduction: Politics of Colonial Conservation. Journal of Southern African Studies 15:143-62.

BeniteZ-Rojo, Antonio, 1992. The Repeating Island: The Caribbean and the Postmodern Perspective. Durham NC: Duke University Press.

BENN, DENNIS, 2004. The Caribbean: An Intellectual History, 1774-2003. Kingston: Ian Randle.

CAIN, P.J. \& A.G. HOPKINS, 1986. Gentlemanly Capitalism and British Expansion Overseas I: The Old Colonial System, 1688-1850. Economic History Review 39:501-25.

CANNY, NiCHOLAS, 1999. Writing Atlantic History: Or, Reconfiguring the History of Colonial British America. Journal of American History 86:1093-1114.

DAVIS, MiKE, 2001. Late Victorian Holocausts: El Niño Famines and the Making of the Third World. New York: Verso.

DeGuZmán, María, 2005. Spain's Long Shadow: The Black Legend, Off-Whiteness, and Anglo-American Empire. Minneapolis: University of Minnesota Press.

DRESCHER, SEYMOUR, 2002. The Mighty Experiment: Free Labor versus Slavery in British Emancipation. Oxford: Oxford University Press.

ESCOBAR, ARTURO, 1995. Encountering Development: The Making and Unmaking of the Third World. Princeton NJ: Princeton University Press.

FOUCAUlT, MiCHEL, 1990. The History of Sexuality: An Introduction. New York: Vintage Books.

FroUdE, JAMES ANTHONY, 1969. The English in the West Indies, or, the Bow of Ulysses. New York: Negro Universities Press. [Orig. 1888.]

GARcía CÁRCEL, RiCARdo \& LOURDES MATEO BRETOS, 1992. La leyenda negra: Historia y opinion. Madrid: Alianza Editorial.

GiBson, Charles (ed.), 1971. The Black Legend: Anti-Spanish Attitudes in the Old World and the New. New York: Random House.

GILroy, PAUl, 1993. The Black Atlantic: Modernity and Double Consciousness. Cambridge MA: Harvard University Press.

GOMARIZ, JOSÉ, 2004. Francisco de Arango y Parreño: El discurso esclavista de la illustración cubana. Cuban Studies 35:45-61.

GOVEIA, ELSA V., 1980. A Study on the Historiography of the British West Indies to the End of the Nineteenth Century. Washington D.C.: Howard University Press. [Orig. 1956.]

GRAHAM, RICHARD, 1990. The Idea of Race in Latin America, 1870-1940. Austin: University of Texas Press.

Halstead, John P., 1983. The Second British Empire: Trade, Philanthropy and Good Government, 1820-1920. Westport: Greenwood Press. 
HANKE, LEWIS, 1971. A Modest Proposal for a Moratorium on Grand Generalizations: Some Thoughts on the Black Legend. Hispanic American Historical Review 51:112-27.

HARLOW, VINCENT T., 1952-1964. The Founding of the Second British Empire, 17631793. New York: Longman.

HiSKetT, MERVYN, 1984. The Development of Islam in West Africa. New York: Longman.

Holt, Thomas, 1992. The Problem of Freedom: Race, Labor and Politics in Jamaica and Britain, 1832-1938. Baltimore MD: Johns Hopkins University Press.

KeEn, Benjamin, 1969. The Black Legend Revisited: Assumptions and Realities. Hispanic American Historical Review 49:703-19.

Las CASas, Bartolomé DE, 2004. A Short Account of the Destruction of the Indies. London: Penguin.

LEWIS, GORDON K., 1983. Main Currents in Caribbean Thought: The Historical Evolution of Caribbean Society in Its Ideological Aspects, 1492-1900. Baltimore: Johns Hopkins University Press.

LOOK LAI, WALTON, 1993. Indentured Labor, Caribbean Sugar: Chinese and Indian Migrants to the British West Indies, 1838-1918. Baltimore MD: Johns Hopkins University Press.

LOVEJOY, PAUL, 1983. Transformations in Slavery: A History of Slavery in Africa. Cambridge: Cambridge University Press.

MaltBy, WiLliam S., 1971. The Black Legend in England: The Development of AntiSpanish Sentiment, 1558-1660. Durham NC: Duke University Press.

Malthus, T.R., 1999. An Essay on the Principle of Population. Oxford: Oxford University Press. [Orig. 1798.]

Merivale, Herman, 1967. Lectures on Colonization and Colonies. New York: Sentry. [Orig. 1841.]

Metha, Uday Singh, 1999. Liberalism and Empire: A Study in Nineteenth-Century British Thought. Chicago: University of Chicago Press.

Mignolo, Walter D., 2000. Local Histories/Global Designs: Coloniality, Subaltern Knowledges, and Border Thinking. Princeton NJ: Princeton University Press.

MOLINA MARTÍNEZ, MigueL, 1991. La leyenda negra. Madrid: NEREA.

MOLONEY, PAT, 2005. Savages in the Scottish Enlightenment's History of Desire. Journal of the History of Sexuality 14(3):237-65.

Nesvig, MARTIN, 2005. Review Essay: Recent Work on Early Western Mexico and the Revival of the Black Legend. Journal of Social History 38:531-38.

NORTHRUP, DAVID, 1995. Indentured Labor in the Age of Imperialism, 1834-1922. Cambridge: Cambridge University Press. 
Pagden, Anthony, 2004. Introduction. In Anthony Pagden (ed.), A Short Account of the Destruction of the Indies. London: Penguin.

PATtERSON, ORLANDO, 1969. The Sociology of Slavery. Rutherford NJ: Fairleigh Dickinson University Press.

POLANYI, KARL, 2001. The Great Transformation: The Political and Economic Origins of Our Time. Boston: Beacon Press. [Orig. 1944.]

PoOvey, Mary, 1993. Figures of Arithmetic, Figures of Speech: The Discourse of Statistics in the 1830s. Critical Inquiry 19:256-76.

ROBINSON, CEDRIC C., 2000. Black Marxism: The Making of the Black Radical Tradition. Chapel Hill: University of North Carolina Press. [Orig. 1976.]

SARmiento, Domingo F., 1960. Life in the Argentine Republic in the Days of the Tyrants: Or, Civilization and Barbarism. New York: Hafner. [Orig. 1868.]

SCOTT, DAVID, 2004. Conscripts of Modernity: The Tragedy of Colonial Enlightenment. Durham NC: Duke University Press.

SEMMEL, BERNARD, 1970. The Rise of Free Trade Imperialism: Classical Political Economy and the Empire of Free Trade and Imperialism, 1750-1850. Cambridge: Cambridge University Press.

Silverblatt, IRENE, 2004. Modern Inquisitions: Peru and the Colonial Origins of the Civilized World. Durham NC: Duke University Press.

SMith, ADAM, 1863. An Inquiry into the Nature and Causes of the Wealth of Nations. Edinburgh: n.p. [Orig. 1776.]

Smith, NeIL, 1990. Uneven Development: Nature, Capital, and the Production of Space. Oxford: Blackwell.

TOMich, DALE, 2003. The Wealth of Empire: Francisco Arango y Parreño, Political Economy, and the Second Slavery in Cuba. Comparative Studies in Society and History 45:4-28.

Trollope, Anthony, 1985. The West Indies and the Spanish Main. New York: Hippocrene Books. [Orig. 1859.]

Trouillot, Michel-Rolph, 1995. Silencing the Past: Power and the Production of History. Boston: Beacon Press.

TURHAN, FILIZ, 2003. The Other Empire: British Romantic Writings about the Ottoman Empire. New York: Routledge.

DANIEL ROOD

1535 Parkwood Pointe Drive

Crescent PA 15046, U.S.A.

<drood@uci.edu> 